\title{
LOAD TRANSFERENCE WITH RUNNING SPEED IN NATURAL REAR-FOOT STRIKE MALE RUNNERS
}

\author{
Ruoyi $\mathrm{LI}^{1,2}$, Hao $\mathrm{LIU}^{1}$, Xuecan CHEN ${ }^{3}$, Jitka BADUROVA 4 , Haojun FAN², Luming YANG ${ }^{1,2^{*}}$ \\ ${ }^{1}$ National Engineering Laboratory for Clean Technology of Leather Manufacture, Sichuan University, Chengdu, 610065, China \\ ${ }^{2}$ Key Laboratory of Leather Chemistry and Engineering, Sichuan University, Chengdu, 610065, China \\ ${ }^{3}$ Fuzhou Customs District P.R. China, Fuzhou, 350000, China \\ ${ }^{4}$ Tomas Bata University, Zlin, 76001, Czech Republic
}

Received: 16.09.2019

Accepted: 03.04.2020

https://doi.org/10.24264/Ifj.20.2.7

\section{LOAD TRANSFERENCE WITH RUNNING SPEED IN NATURAL REAR-FOOT STRIKE MALE RUNNERS}

ABSTRACT. The purpose of this study was to identify the influence of running speed on plantar pressure, and to use a load transfer algorithm to investigate the load transference in healthy recreational male runners who had a natural rear-foot strike pattern. Totally, 49 healthy males participated in this study, 39 of them (age $22.8 \pm 1.8$ years, weight $65.6 \pm 7.9 \mathrm{~kg}$, height $171.9 \pm 4.0 \mathrm{~cm}$ ) were identified as rear-foot strike runners. Data of pressure parameters, including maximum force, peak pressure, contact area and force-time integral (FTI) was recorded by Pedar-X insole plantar pressure measurement system at 8 different speeds $(5,6,7,8,9,10,11,12 \mathrm{~km} / \mathrm{h})$. The results indicated that with the increase of running speed, plantar pressure significantly increased under all foot regions except for the big toe. Faster running speeds resulted in significant lower FTI in all foot regions except for lateral midfoot and heel. Medial metatarsal, central metatarsal, and big toe were the main loading regions for rear-foot strike male runners during running. Load transferred from medial foot to lateral foot in transverse direction, and from toes to metatarsal, midfoot and heel in the longitudinal direction with increasing speeds. As a component of the spring mechanism, the arch played a key role in supporting and transferring loads.

KEY WORDS: running, speed, load transfer, rear-foot strike, plantar pressure

\section{TRANSFERUL DE SARCINĂ ÎN FUNCTIIE DE VITEZA DE ALERGARE ÎN CAZUL ALERGĂTORILOR DE SEX MASCULIN CARE ATING SOLUL CU RETROPICIORUL}

REZUMAT. Scopul acestui studiu a fost de a identifica influența vitezei de alergare asupra presiunii plantare și de a utiliza un algoritm de transfer de sarcină pentru a investiga transferul de sarcină la alergătorii amatori sănătoși de sex masculin care au o tendință naturală de a atinge solul cu retropiciorul. În total, 49 de bărbați sănătoși au participat la acest studiu, 39 dintre ei (vârsta 22,8 $\pm 1,8$ ani, greutatea $65,6 \pm$ $7,9 \mathrm{~kg}$, înălțimea $171,9 \pm 4,0 \mathrm{~cm}$ ) au fost identificați ca alergători care ating solul cu retropiciorul. Datele parametrilor de presiune, cuprinzând forța maximă, presiunea maximă, zona de contact și integrala forță-timp (FTI) au fost înregistrate de sistemul de măsurare a presiunii plantare Pedar-X la 8 viteze diferite $(5,6,7,8,9,10,11,12 \mathrm{~km} / \mathrm{h})$. Rezultatele au indicat că odată cu creșterea vitezei de alergare, presiunea plantară a crescut semnificativ în toate regiunile piciorului, cu excepția degetului mare. Viteza de alergare mai rapidă a condus la o scădere semnificativă a FTI în toate regiunile piciorului, cu excepția zonei laterale și a călcâiului. Principalele regiuni în care s-au înregistrat presiuni mari în cazul alergătorilor de sex masculin care ating solul cu retropiciorul în timpul alergării au fost: zonele mediană și centrală ale metatarsienelor și degetul mare. Sarcina se transferă din zona mediană în zona laterală în direcție transversală, și de la degete la metatarsiene, zona mediană și călcâi în direcție longitudinală odată cu creșterea vitezei. Ca o componentă a mecanismului de arc, bolta plantară a jucat un rol cheie în susținerea și transferul presiunii.

CUVINTE CHEIE: alergare, viteză, transfer de sarcină, atingerea solului cu retropiciorul, presiune plantară

\section{TRANSFERT DE CHARGE EN FONCTION DE LA VITESSE DE COURSE POUR LES COUREURS DU SEXE MASCULIN QUI TOUCHENT LE SOL AVEC L'ARRIÈRE-PIED}

RÉSUMÉ. Le but de cette étude était d'identifier l'influence de la vitesse de course sur la pression plantaire et d'utiliser un algorithme de transfert de charge pour étudier le transfert de charge chez des coureurs amateurs du sexe masculin en bonne santé qui ont une tendance naturelle à toucher le sol avec l'arrière-pied. Au total, 49 hommes en bonne santé ont participé à cette étude, 39 d'entre eux (âge 22,8 \pm 1,8 ans, poids $65,6 \pm 7,9 \mathrm{~kg}$, taille $171,9 \pm 4,0 \mathrm{~cm}$ ) ont été identifiés comme des coureurs qui touchent le sol avec l'arrière-pied. Les données des paramètres de pression, y compris la force maximale, la pression maximale, la zone de contact et l'intégrale force-temps (FTI) ont été enregistrées par le système de mesure de la pression plantaire Pedar- $X$ à 8 vitesses différentes $(5,6,7,8,9,10,11,12 \mathrm{~km} / \mathrm{h})$. Les résultats ont indiqué qu'avec l'augmentation de la vitesse de course, la pression plantaire a augmenté de manière significative dans toutes les régions du pied à l'exception du gros orteil. Des vitesses de course plus rapides ont entraîné une baisse significative de la FTI dans toutes les régions du pied, à l'exception du milieu du pied et du talon. Le métatarsien médial, le métatarsien central et le gros orteil étaient les principales régions de chargement des coureurs du sexe masculin qui touchent le sol avec l'arrière-pied pendant la course. La charge est transférée du pied médial au pied latéral dans le sens transversal, et des orteils au métatarsien, au milieu du pied et au talon dans le sens longitudinal à mesure que la vitesse augmente. En tant que composant du mécanisme à ressort, la voûte plantaire a joué un rôle clé dans le soutien et le transfert des pressions.

MOTS CLÉS : course, vitesse, transfert de charge, toucher le sol avec l'arrière-pied, pression plantaire

"Correspondence to: Assoc. Prof. Luming YANG, Key Laboratory of Leather Chemistry and Engineering, Sichuan University, No.24 South Section 1, Yihuan Road, Chengdu, China, 610065, Phone: +86 1862811 7800, email: ylmIl1982@126.com 


\section{INTRODUCTION}

During the past few decades, running as a recreational activity has become one of the most popular exercises to maintain health. However, running could cause discomfort and injuries in the lower extremity and the foot [1, 2]. A recent meta-analysis revealed that, the reported incidence rate of running-related injury ranged from 2.5 to 33.0 injuries per 1000 hours of running [3]. It can be suggested that the lower limb injuries are associated with excessive high speed running exposure [4, 5]. Furthermore, load distribution plays an essential role for the detection of injuries in the foot $[6,7]$. Since running speed effects human biomechanical features, it is necessary to explore how running speed effects human bodies.

The influence of running speed on plantar pressure has been reported in several previous studies. I-Ju Ho et al. found that the peak pressure significantly increased except for the medial forefoot and the hallux with the increase of running speed [8]. However, the plantar pressure was compared only in three speeds. Fourchet et al. compared the plantar pressure distribution in highly trained adolescent runners at low versus high running velocity [9]. But it is still unclear in the recreational adult male runners. Kernozek et al. reported that all plantar loading variables increased with the exception of contact area when treadmill running speed was increased from $2.24 \mathrm{~m} / \mathrm{s}$ to $3.13 \mathrm{~m} / \mathrm{s}$ [10]. Based on the aforementioned studies, it was found that the results of these studies had not reached a consensus. This could be due to the use of many different characteristics, such as the subdivisions of plantar location. An additional important point is that the potentially confounding influence of speed on pressure values was not consistently controlled. One of the influences was the foot-strike pattern. Previous research has revealed three different ways the foot can collide with the ground [11]: heel landing first (rear-foot strike, RFS), ball of the foot landing first (fore-foot strike, FFS) and the heel and ball of the foot land simultaneously (mid-foot strike, MFS). The three ways are different at foot landing, load transference and pressure distribution during running $[12,13]$, but these differences were not taken into account in the above studies. Since $75-80 \%$ of shod endurance runners were RFS [14], this study chose to focus solely on RFS. Likewise, little attention had been given to the possibility that different shoes used in these studies had effect on plantar pressure distribution in these studies. Unlike other studies, this study concentrated on recreational adult male runners with natural RFS pattern and further used standard shoes. In addition, a wide range of running speeds from $5 \mathrm{~km} / \mathrm{h}$ to $12 \mathrm{~km} / \mathrm{h}$ were selected as a supplementary for previous studies.

Old study had indicated to use algorithm and diagram to identify how the load transfer on foot in different situation [15-17]. Bus et al. used a load transfer diagram to show how plantar pressure was relieved when using forefoot offloading shoes in diabetic foot [15]. Mingyu Hu et al. designed an algorithm to quantify the plantar force transference in children from 2-6 years [16]. In our study, it is the first time a load transfer algorithm is used to explore how the load transfers with the increase of running speed. Moreover, load transfer algorithm was improved in order to better suit this study. Many studies had investigated the influence of running speed on plantar pressure distribution, but how the plantar pressure distribution differences come and how the load transfers with the increase of running speed were still unclearly. The use of this load transfer analysis method can help reach a better understanding of the mechanisms of how the foot structure acts to transfer load in different foot regions.

Therefore, the purpose of this study was to identify the influence of running speed on plantar pressure, and to use a load transfer algorithm to investigate the load transference in healthy recreational male runners who had a natural rear-foot strike pattern. We hypothesized that faster running speed would result in an increase in plantar pressure measurements, and load may transfer along the transverse or longitudinal arch in anterior-posterior and medial-lateral directions.

\section{METHODS}

\section{Participants}

In total, 49 healthy males (age $22.8 \pm 1.7$ years, body mass $65.3 \pm 7.8 \mathrm{~kg}$, height $172.1 \pm$ 
$3.8 \mathrm{~cm}$ ), without known neurologic or lower extremity orthopedic pathology participated in this study. They were all right leg dominant recreational runners who ran about one hour per week. Informed consent was obtained from each participant, and the study was approved by the Ethics Committee of Sichuan University. According to Altman and Davis's study [18], participants were defined into rear-foot strike and other foot strike pattern (mid-foot strike and fore-foot strike). 39 males (age $22.8 \pm 1.8$ years, weight $65.6 \pm 7.9 \mathrm{~kg}$, height $171.9 \pm 4.0$ $\mathrm{cm}$ ) were identified as rear-foot strike and were focused on in this study. Plantar pressure factors were measured by Novel Pedar-X in-shoe system (Novel, Munich, Germany). Each pressure insole contained 99 capacitive sensors that were calibrated prior to data collection. The insole was flexible so that it could be easily placed into the bottom of the shoe. The sampling rate was set to a frequency of $50 \mathrm{~Hz}$. All the participants were sized and fitted to a pair of standard shoes (Nike Free 5.0, Nike, America) to counter a possible bias of shoe type or shoe construction on the subjects' running style. The shoes size was a US size 8 . The shoes were purchased solely for Pedar data collection and had not been used for any other purpose. And the participants were requested to wear the same socks which were provided during the test. The treadmill (King Smith T211\&T221, China) consisted of a walking surface of $1220 \times 420 \mathrm{~mm}$ and could be set to speeds from $0.0 \mathrm{~km} / \mathrm{h}$ to $16.0 \mathrm{~km} / \mathrm{h}$ accurately. As for Asian recreational male runners, during the pre-test, $5 \mathrm{~km} / \mathrm{h}$ was found to be the lowest speed that participants could jog. Meanwhile, 12 $\mathrm{km} / \mathrm{h}$ was the highest attainable speed for most participants found among Asian recreational male runners. Therefore, the range of running speed selected in this study was from $5 \mathrm{~km} / \mathrm{h}$ to $12 \mathrm{~km} / \mathrm{h}$.

\section{Procedure}

Plantar pressure factors were recorded as participants wearing the same socks and standard shoes ran on the treadmill at 8 different speeds $(5,6,7,8,9,10,11,12 \mathrm{~km} / \mathrm{h})$ with zero slope. Data of pressure parameters, including maximum force, peak pressure, contact area and force-time integral (FTI) was recorded by Pedar- $X$ insole plantar pressure measurement system.
Prior to testing, all participants were informed about the procedures. A warmup was instructed that would include regular stretches as well as running at a preferred speed so that participants could familiarize themselves with the treadmill and standard shoes. After the warmup, participants were requested to begin to run on the treadmill in a self-selected speed, allowing their foot strike pattern to be verified from the data collected. Next, treadmill settings were adjusted and data collected at each speed during participants' running process. Participants were allowed one-minute acclimation period before data collection began. Data would be collected for 20 seconds at each speed respectively. A brief rest period was provided (approximately one minute) if the participants needed during the test.

\section{Statistical Analysis}

For the analysis of plantar pressure distribution, plantar foot was divided into eight anatomical regions (Figure 1): big toe (BT), toes 2-5 (T2-5), medial metatarsal (MM), central metatarsal (CM), lateral metatarsal (LM), medial midfoot (MMF), lateral midfoot (LMF) and heel (H). Analysis of in-shoe pressure data was done using Novel software. The right foot of each participant was used during statistical analysis [19]. For each runner, the mean plantar pressure parameters of the right foot were calculated based on five successful consecutive steps chosen from 20 seconds of treadmill running data. Statistical analysis was conducted by SPSS17.0. By application of Kolmogorov Smirnov, all data were found to be in normal distribution. A one-Way ANOVA was used to examine the differences in plantar pressure parameters for each region among the different running speeds. The level of $\alpha=0.05$ ( $p \leq 0.05$ ) was perceived as significant for statistical analyses. 


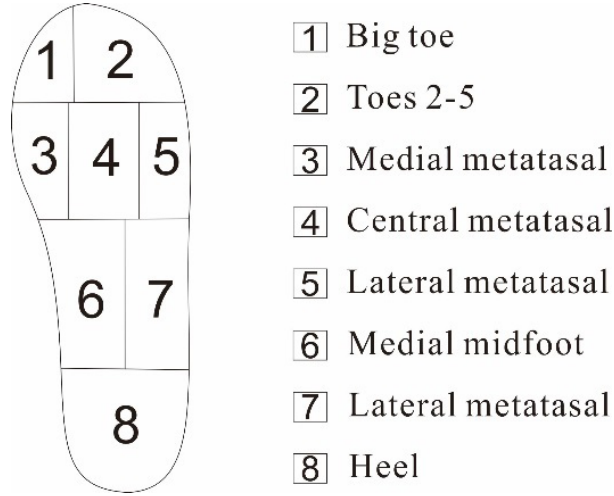

Figure 1. Foot regions

\section{Load Transfer Algorithm}

Plantar load transference has been explored to establish a correlation between the varied parts of the foot structure [16]. A load transfer algorithm was improved to quantify the plantar load transference with the running speeds increasing from $5 \mathrm{~km} / \mathrm{h}$ to $12 \mathrm{~km} / \mathrm{h}$ in healthy rear-foot strike male runners (Figure 3 ). The FTI is a measure of the force impulse or the load applied to the foot in a given region [20]. In this study, inter-regional force transfer was assessed by relative FTI using the load transfer algorithm. Relative FTI was the regional FTI value normalized to total foot FTI. Relative FTI (\%) = $100 \times\left(\right.$ FTI (foot mask) / $\sum$ FTI (foot mask)). Since the participants may change their gait patterns from jogging to fast running with the increase of running speed, the comparison of regional force impulses among different running speeds allows the calculation of load transfer from a region where load is reduced in one speed to a region where load is increased in comparison with another speed. Furthermore, load transference was divided into two parts, transference in longitudinal (anterior-posterior) direction and transference in transverse (media-lateral) direction, in order to observe the transference respectively. Certain rules for the calculation were formulated, as follows:

Four levels are defined following the anatomical structure along the longitudinal direction: toes (Level 1, BT and T2-5), metatarsal (Level 2, MM, CM and LM), midfoot (Level 3, MMF and LMF) and heel (Level 4, H). The numbers in each foot region are the difference value of relative FTI between the two speeds (Figure 3).

Load transfer calculation starts within level from high value regions to low value regions. The transference is in transverse (medial-lateral) direction. After the transfer, the values in each region at the same level tend to equal (even in negative values). Load transfer occurs between adjacent anatomical regions first, and then between the further regions. After the transfer, the altered values of relative FTI is exhibited in the red color.

After the within-level transfer, load transfers cross level from high value regions to low value regions. The transference is in longitudinal (anterior-posterior) direction. After the transfer, the values in each region tend to zero. Load transfer occurs between adjacent anatomical regions first, and then between the further regions. After the transfer, the altered values of relative FTI is exhibited in the red color (generally is zero).

\section{RESULTS}

Significant differences were found in maximum force, peak pressure, contact area and FTI among different running speeds. The faster running speeds resulted in significant higher values at maximum force and peak pressure under all foot regions except for the big toe (Table 1, Figure 2). Peak pressure was concentrated in MM, CM and BT. Contact area was found significantly increased in T2-5, CM and LM with the increase of running speed (Table 2).With the increase of running speed, significant lower values in FTI were found under all plantar regions except for LMF and $\mathrm{H}$ (Table 3). MM, CM and BT were the main loading regions for rearfoot strike male runners during running. 


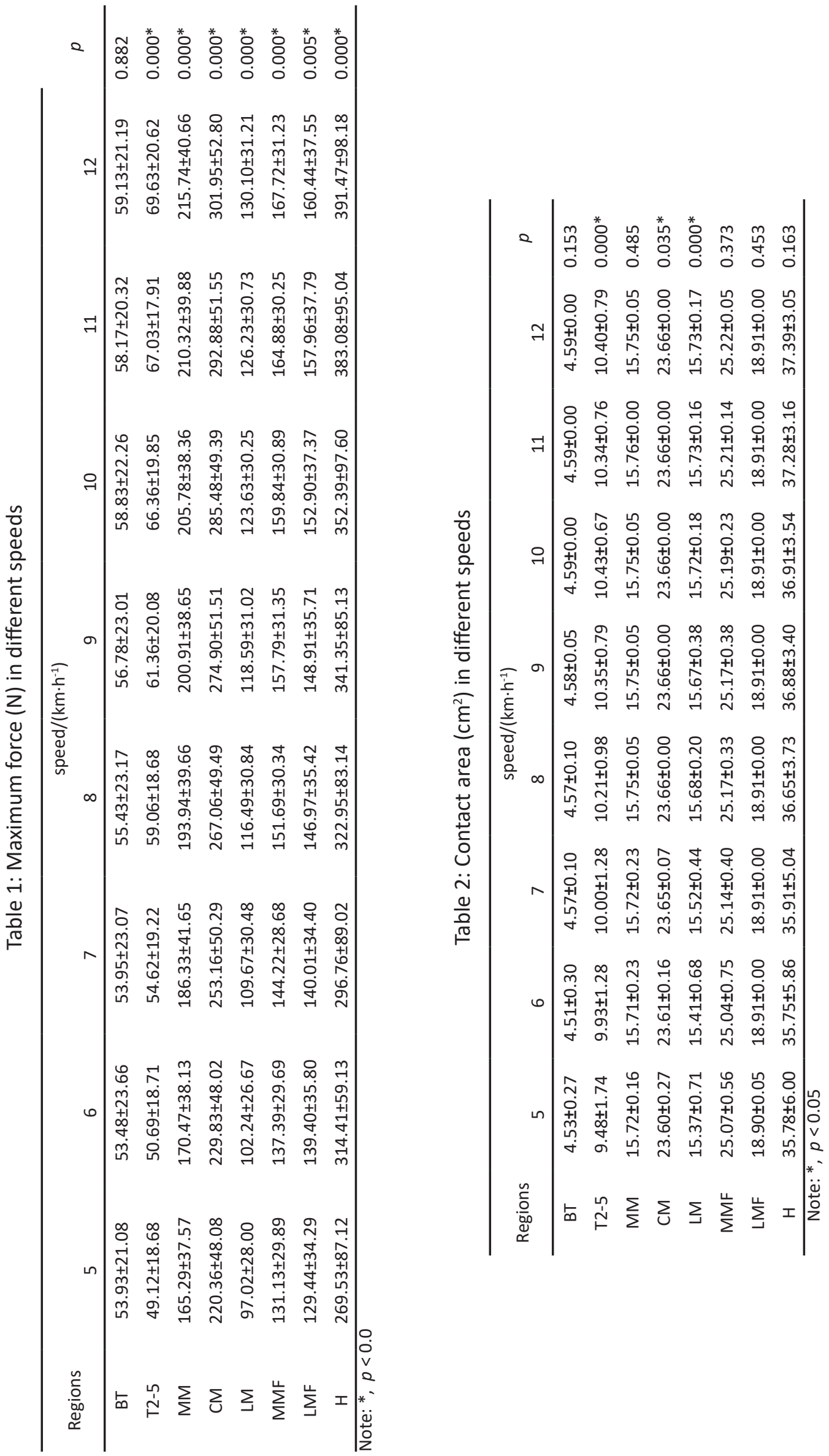




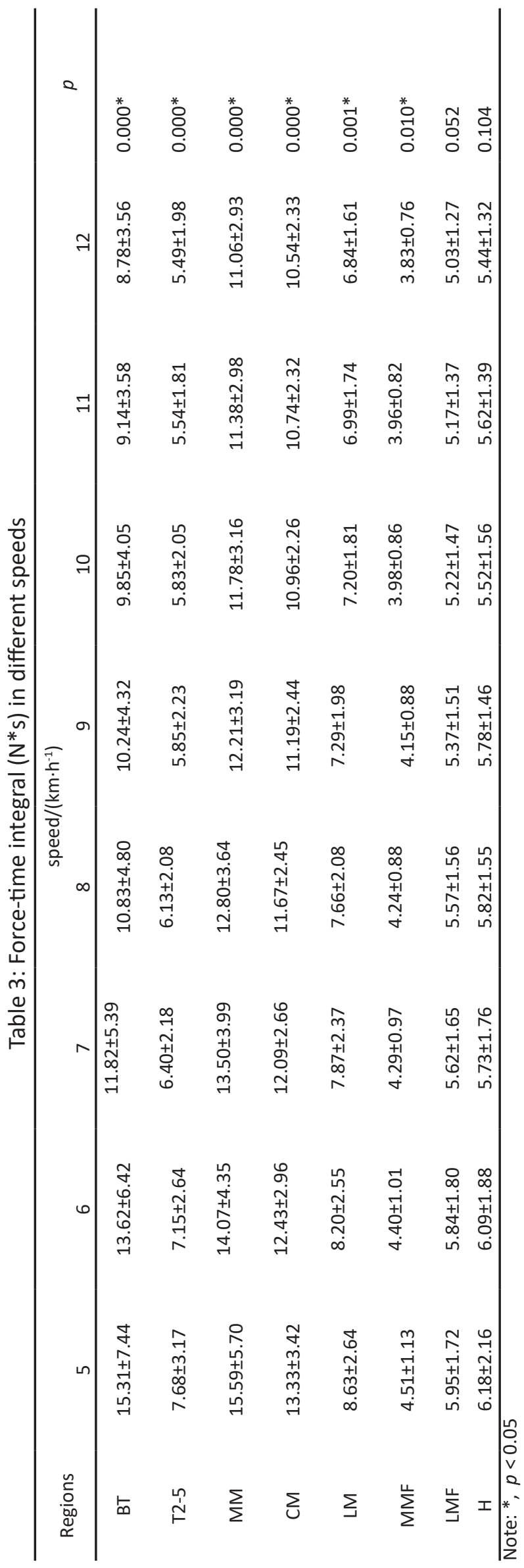


$(\mathrm{kPa})$
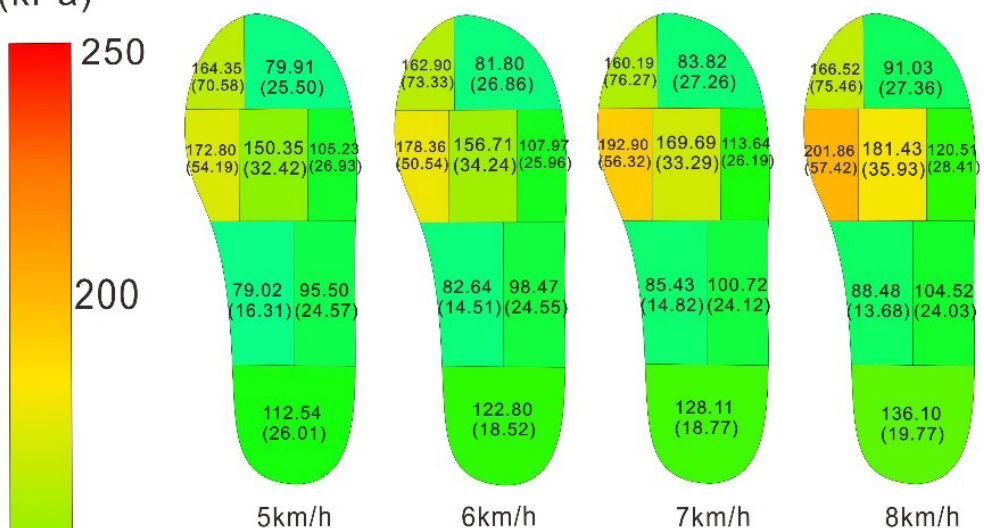

150

$6 \mathrm{~km} / \mathrm{h}$

$7 \mathrm{~km} / \mathrm{h}$

$8 \mathrm{~km} / \mathrm{h}$
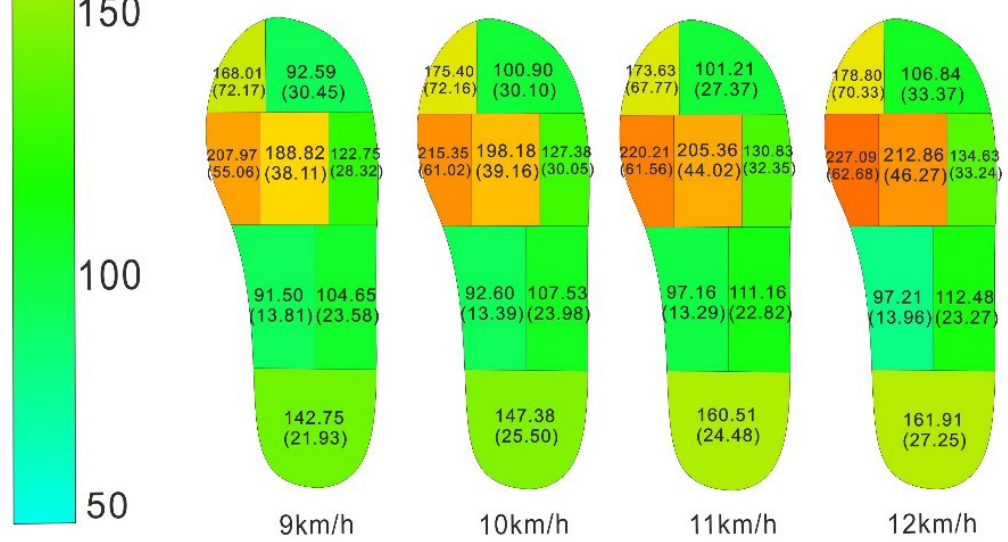

Figure 2. Peak pressure in $5 \mathrm{~km} / \mathrm{h}-12 \mathrm{~km} / \mathrm{h}$ ( $p$ value: $\mathrm{BT}, p=0.948 ; \mathrm{T} 2-5, p<0.001 ; \mathrm{MM}, p<0.001$; CM, $p<0.001 ;$ LM, $p<0.001 ;$ MMF, $p<0.001 ;$ LMF, $p=0.022 ; \mathrm{H}, p<0.001$ )

Load transferred along the transverse and longitudinal arch in anterior-posterior and medialateral directions (Figure 3). Force transference was only indicated between the $5 \mathrm{~km} / \mathrm{h}$ and $8 \mathrm{~km} / \mathrm{h}$ groups, as well as the $8 \mathrm{~km} / \mathrm{h}$ and 12 $\mathrm{km} / \mathrm{h}$ groups, shown in Figure 3. In the pre-test, $5 \mathrm{~km} / \mathrm{h}$ and $12 \mathrm{~km} / \mathrm{h}$ were found to the lowest speed and highest speed for Asian recreational male runners to keep running. Therefore, $5 \mathrm{~km} / \mathrm{h}$ and $12 \mathrm{~km} / \mathrm{h}$ were chosen as typically jogging and fast running condition. Meanwhile, $8 \mathrm{~km} / \mathrm{h}$ was found to nearest the preferring speed in pretest. In the post hoc test, we found that when the speed raised up to $8 \mathrm{~km} / \mathrm{h}$, some of the plantar regions developed significant lower FTI values comparing with $5 \mathrm{~km} / \mathrm{h}$. Therefore, $5 \mathrm{~km} / \mathrm{h}$, $8 \mathrm{~km} / \mathrm{h}$ and $12 \mathrm{~km} / \mathrm{h}$ were chosen as jogging, normal running and fast running speeds to show the load transference existing with the increase of running speed. Difference values of relative FTI (\%) between $5 \mathrm{~km} / \mathrm{h}$ with $8 \mathrm{~km} / \mathrm{h}$, and $8 \mathrm{~km} / \mathrm{h}$ with $12 \mathrm{~km} / \mathrm{h}$ were indicated in Table 4 . Because FTI significantly decreased in BT, T2-5, MM, CM, $L M$ and MMF, this study would focus on these regions to find how the load transfer. According to Figure 3 , in the transverse direction, load transferred from $\mathrm{BT}$ to $\mathrm{T} 2-5$, from $\mathrm{MM}$ to $\mathrm{CM}$ and LM, from MMF to LMF ( $5 \mathrm{~km} / \mathrm{h}$ to $8 \mathrm{~km} / \mathrm{h}$ ). In the longitudinal direction, load transferred from level 1 to level 2, level 3 and level 4, that was from toes to metatarsal, midfoot and heel. In other words, load transferred mainly from medial to lateral in transverse direction and from anterior to posterior in longitudinal direction with the increase of running speed. 
Force transference from $5 \mathrm{~km} / \mathrm{h}$ to $8 \mathrm{~km} / \mathrm{h}$

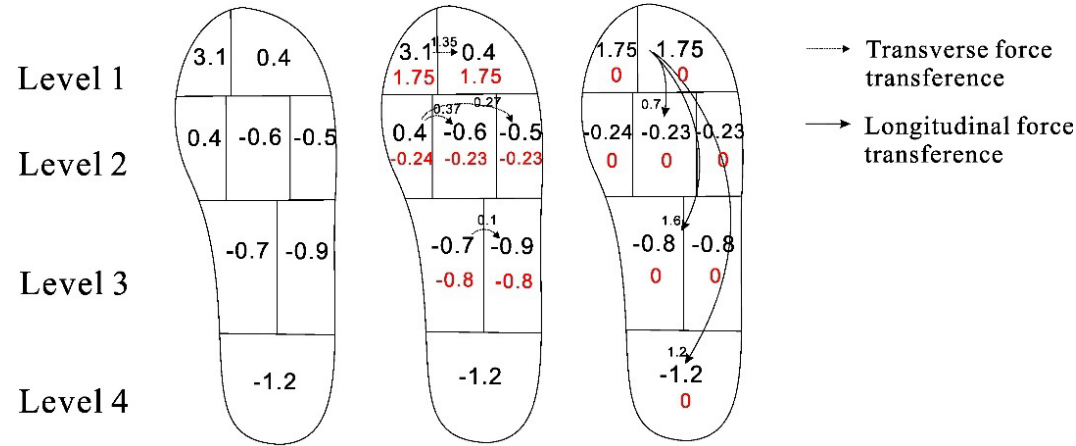

Force transference from $8 \mathrm{~km} / \mathrm{h}$ to $12 \mathrm{~km} / \mathrm{h}$
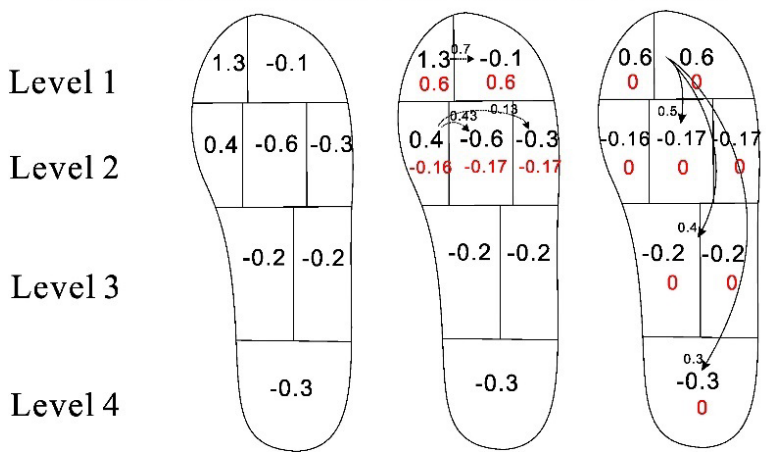

Figure 3. Force transference

Table 4: Relative FTI (\%) and the difference value

\begin{tabular}{cccccc}
\hline \multirow{2}{*}{ Foot regions } & \multicolumn{5}{c}{ speed } \\
& 5 & 8 & 12 & diff.5-8 & diff.8-12 \\
\hline BT & 19.7 & 16.6 & 15.3 & 3.1 & 1.3 \\
T2-5 & 10.0 & 9.6 & 9.7 & 0.4 & -0.1 \\
MM & 20.0 & 19.6 & 19.2 & 0.4 & 0.4 \\
CM & 17.1 & 17.7 & 18.3 & -0.6 & -0.6 \\
LM & 11.2 & 11.7 & 12.0 & -0.5 & -0.3 \\
MMF & 5.8 & 6.5 & 6.7 & -0.7 & -0.2 \\
LMF & 7.8 & 8.7 & 8.9 & -0.9 & -0.2 \\
H & 8.4 & 9.6 & 9.99 & -1.2 & -0.3 \\
\hline
\end{tabular}

\section{DISCUSSION}

In this study, the plantar pressure of 39 healthy rear-foot strike male runners was measured and their plantar load transfer were analyzed by a load transfer algorithm. The results showed load transferred along the transverse direction from medial part of the foot to lateral part of the foot, as well as along the longitudinal direction from toes to metatarsal, midfoot and rearfoot. The medial metatarsal, the central metatarsal and the big toe were the main loading regions for rear-foot strike male runners during running, and medial to lateral, anterior to posterior load transfer were typical. According to the above tracks, the load-transfer mechanism of healthy rear-foot strike Asian male runners was quantified.

With the increase of running speed, the foot had a stronger support to hold the body and generate the propulsion, which could result in higher impact on the foot. While maximum force and peak pressure were generally increased across all regions of the foot with the increase of running speed, it was disproportionately 
increased more in the metatarsal area. As the main loading regions of the foot during running, maximum force and peak pressure of $\mathrm{MM}$ and $\mathrm{CM}$ increased greatly, as an average of $31.1 \%, 31.4 \%$ on $\mathrm{MM}$ and $37.0 \%, 41.6 \%$ on $\mathrm{CM}$. In the forefoot, the highest peak pressure was found under MM, which was in accordance with De Cock's work [21]. According to Figure 2, MM, CM and BT demonstrated higher pressure across all of the speeds, which might suggest that these regions had higher risks for stress fracture, especially at high speed running [22]. Running shoes should be designed to provide better protection to the metatarsal in order to avoid the injuries that can occur from excessive impact.

With the increase of running speed, FTI was found significantly decreased under all the plantar regions except for $\mathrm{H}$. It was because that as an influence factor of FTI, the ground contact time decreased. With the increase of running speed, runners showed shorter stride and higher cadence at higher running speed, which indicated that time spent on one gait decreased. Moreover, the actual duration of stance and swing during running gait are variable depending on the running speed. Faster speeds results in decreased support and increased float periods [23], which suggested that the ground contact time on each foot decreased during running gait at higher speed.

Running used a spring mass model in the compliant lower limb in which muscles and tendons sequentially stored and then released energy during the stance phase [24, 25]. As a component of the spring mechanism, the longitudinal arch had an important role as shock absorber for mechanical shock and load during human movement. The longitudinal arch of the human foot compressed and recoiled in response to being cyclically loaded. Foot suffered higher impact with the increase of speed, so the foot arch became flatter for absorbing shocks and made the contact area expanded. This is the reason for increase of contact area. Load transferred along the longitudinal direction from toes to metatarsal, midfoot and heel, which may also suggest that in higher running speed, the spring mechanism become more active to absorb loading forces and produce higher forward propulsion rather than the toes.
To our knowledge, this is the first study to use a load transfer algorithm to analyze the load transfer with the increase of running speed. The load transfer algorithm was also quite different from the old one. In Bus's transfer algorithm [15], load transfer can only occur between adjacent anatomical regions. Because Bus's studies were about how the custom-made insoles or forefoot offloading shoes relief the pressure, it would be more important to explore how the pressure is relieved in one foot region after another region. But in our study, load transfer occurred between adjacent anatomical regions first, and then between the further regions, which could show the origin of the load directly. In Mingyu Hu's study [16], load could only transfer from positive regions to negative ones. But in our study, especially in the within-level transfer, load transferred from high value regions to low value regions, even could transfer from positive region to positive one, and from negative region to negative one. The improved load transfer algorithm was more proper to show the differences of load distribution for this study.

Breine [26] indicated a transition towards a more anterior foot strike pattern in shod runners with increasing speeds from $3.2 \mathrm{~m} / \mathrm{s}$ $(11.5 \mathrm{~km} / \mathrm{h})$ to $6.2 \mathrm{~m} / \mathrm{s}(22.3 \mathrm{~km} / \mathrm{h})$. In our study, only one participant transferred from rear-foot stride pattern to non-rear-foot stride pattern. The reason might be that the highest speed observed in our study was $12 \mathrm{~km} / \mathrm{h}$, but Breine explored higher speed from $3.2 \mathrm{~m} / \mathrm{s}(11.5 \mathrm{~km} / \mathrm{h})$ to $6.2 \mathrm{~m} / \mathrm{s}(22.3 \mathrm{~km} / \mathrm{h})$ larger than this study. The change of foot strike patterns might occur more frequently in higher speed. Rear-foot strike Asian male shod runners might not change their foot strike patterns when the running speeds are less than $12 \mathrm{~km} / \mathrm{h}$.

There are a number of limitations to this study. A potential limitation might be the use of treadmill. Treadmill could control the speed accurately during the test. But it was known that running on the treadmill was associated with a lower magnitude maximum plantar pressure and a lower maximum plantar force in plantar areas [27]. The measurements on the treadmill could be accurately known but it was not equivalent to the measurements overground. Besides, 
this study was conducted in healthy Asian recreational male runners with habitual rearfoot strike pattern, and it was unknown if the findings would be replicated in fore-foot strike and mid-foot strike runners or non-Asians.

\section{CONCLUSION}

This study demonstrates the influence of running speed on plantar pressure, and show how the load transfer with the increase of running speed in rear-foot strike male runners. With the increase of running speed, maximum force and peak pressure significantly increased under all foot regions except for the big toe. Faster running speeds resulted in significantly lower FTI in all foot regions except for lateral midfoot and heel. MM, CM and BT were the main loading regions for rear-foot strike male runners during running. $\mathrm{MM}, \mathrm{CM}$ and $\mathrm{BT}$ had higher risks for running-related injuries as these regions demonstrated highest pressure across all the speeds, especially at high speed running. Running shoes should be designed to provide better protection to metatarsal to avoid the injury. As a component of the spring mechanism, the arch played a key role in supporting and transferring loads. Load transferred along the longitudinal direction from toes to metatarsal, midfoot and heel, which suggest that in higher running speed, the spring mechanism becomes more active to absorb loading forces and produce higher forward propulsion rather than the toes. Load transferred from medial foot to lateral foot in transverse direction. These findings can improve our understanding of the structurefunction relationship of the foot, and reveal the need for special consideration in sports shoes design in order to increase comfort and avoid running-related injury.

\section{Acknowledgments}

This work was supported by the National Natural Science Foundation of China [grant numbers: 11502154]. The authors would like to acknowledge all the experimenters for participant recruitment and data collection, and to acknowledge all the participants who made this study possible.
Conflict of Interest

There were no conflicts of interest with other authors or institution for this study.

\section{REFERENCES}

1. Duhig, S., Shield, A.J., Opar, D., Gabbett, T.J., Ferguson, C., Williams, M., Effect of highspeed running on hamstring strain injury risk, BrJSports Med, 2016, 50, 24, 1536-40, https:// doi.org/10.1136/bjsports-2015-095679.

2. Mann, R., Malisoux, L., Urhausen, A., Meijer, K., Theisen, D., Plantar pressure measurements and running-related injury: A systematic review of methods and possible associations, Gait Posture, 2016, 47, 1-9, https://doi.org/ 10.1016/j.gaitpost.2016.03.016.

3. Videbaek, S., Bueno, A.M., Nielsen, R.O., Rasmussen, S., Incidence of Running-Related Injuries Per $1000 \mathrm{~h}$ of running in Different Types of Runners: A Systematic Review and Meta-Analysis, Sports Med, 2015, 45, 7, 1017-26. https://doi.org/ 10.1007/s40279015-0333-8.

4. Elliott, M.C., Zarins, B., Powell, J.W., Kenyon, C.D., Hamstring muscle strains in professional football players: a 10-year review, American J Sports Med, 2011, 39, 4, 843-50, https://doi. org/ 10.1177/0363546510394647.

5. Gabbett, T.J., Ullah, S., Relationship between running loads and soft-tissue injury in elite team sport athletes, J Strength Cond Res, 2012, 26, 4, 953-60, https://doi.org/10.1519/ JSC.0b013e3182302023.

6. Bertelsen, M.L., Hulme, A., Petersen, J., Brund, R.K., Sorensen, H., Finch, C.F., Parner, E.T., Nielsen, R.O., A framework for the etiology of running-related injuries, Scand I Med Sci Sports, 2017, https://doi.org/10.1111/ sms.12883.

7. Rice, H., Nunns, M., House, C., Fallowfield, J., Allsopp, A., Dixon, S., High medial plantar pressures during barefoot running are associated with increased risk of ankle inversion injury in Royal Marine recruits, Gait 
Posture, 2013, 38, 4, 614-8, https://doi.org/ 10.1016/j.gaitpost.2013.02.001.

8. Ho, I.-J., Hou, Y.-Y., Yang, C.-H., Wu, W.-L., Chen, S.-K., Guo, L.-Y., Comparison of plantar pressure distribution between different speed and incline during treadmill jogging, $J$ Sport Sci Med, 2010, 9, 1, 154-60.

9. Fourchet, F., Kelly, L., Horobeanu, C., Loepelt, H., Taiar, R., Millet, G.P., Comparison of plantar pressure distribution in adolescent runners at low vs. high running velocity, Gait Posture, 2012, 35, 4, 685-7, https://doi.org/10.1016/j. gaitpost.2011.12.004.

10. Kernozek, T.W., Zimmer, K.A., Reliability and Running Speed Effects of In-shoe Loading Measurements During Slow Treadmill Running, Foot Ankle Int, 2000, https://doi.or g/10.1177/107110070002100906.

11. Lieberman, D.E., Venkadesan, M., Werbel, W.A., Daoud, A.I., D’Andrea, S., Davis, I.S., Mang'Eni, R.O., Pitsiladis, Y., Foot strike patterns and collision forces in habitually barefoot versus shod runners, Nature, 2010, 463, 7280, 531-5, https://doi.org/10.1038/ nature08723.

12. Perl, D.P., Daoud, A.I., Lieberman, D.E., Effects of footwear and strike type on running economy, Med Sci Sports Exerc, 2012, 44, 7, 1335-43, https://doi.org/10.1249/MSS. Ob013e318247989e.

13. Rooney, B.D., Derrick, T.R., Joint contact loading in forefoot and rearfoot strike patterns during running, J Biomech, 2013, 46, 13, 2201-6, https://doi.org/10.1016/j. jbiomech.2013.06. 022.

14. Hasegawa, H., Yamauchi, T., Kraemew, W.J., Foot strike patterns of runners at the $15-\mathrm{km}$ point during an elite-level half marathon, J Strength Cond Res, 2007, 21, 3, 888-93, https://doi.org/10.1519/00124278200708000-00040.

15. Bus, S.A., van Deursen, R.W., Kanade, R.V., Wissink, M., Manning, E.A., van Baal, J.G., Harding, K.G., Plantar pressure relief in the diabetic foot using forefoot offloading shoes, Gait Posture, 2009, 29, 4, 618-22, https://doi. org/10.1016/j.gaitpost.2009.01.003.

16. Hu, M., Zhou, N., Xu, B., Chen, W., Wu, J., Zhou, J., The mechanism of force transference in feet of children ages two to six, Gait Posture, 2017, 54, 15-9, https://doi.org/10.1016/j. gaitpost.2017.02.019.

17. Li, R., Liu, H., Guo, M., Badurova, J., Yang, L., Fan, H., Differences in loading patterns between fast walking and jogging at the same speed in male adults, J Leather Sci Eng, 2020, 2, 11, https://doi.org/10.1186/s42825-02000021-4.

18. Altman, A.R., Davis, I.S., A kinematic method for footstrike pattern detection in barefoot and shod runners, Gait Posture, 2012, 35, 2, 298-300, https://doi.org/10.1016/j. gaitpost.2011.09.104.

19. Menz, H.B., Two feet, or one person? Problems associated with statistical analysis of paired data in foot and ankle medicine, Foot, 2004, 14, 1, 2-5, https://doi.org/10.1016/s09582592(03)00047-6.

20. Bus, S.A., Ulbrecht, J.S., Cavanagh, P.R., Pressure relief and load redistribution by custom-made insoles in diabetic patients with neuropathy and foot deformity, Clin Biomech, 2004, 19, 6, 629-38, https://doi. org/10.1016/j.clinbiomech.2004.02.010.

21. De Cock, A., Willems, T., Witvrouw, E., Vanrenterghem, J., De Clercq, D., A functional foot type classification with cluster analysis based on plantar pressure distribution during jogging, Gait Posture, 2006, 23, 3, 39-47, https://doi.org/10.1016/j. gaitpost.2005.04.011.

22. Liong, S.Y., Whitehouse, R.W., Lower extremity and pelvic stress fractures in athletes, $\mathrm{Br} J$ Radiol, 2012, 85, 1016, 1148-56, https://doi. org/10.1259/bjr/78510315.

23. Lohman, E.B., 3rd, Balan Sackiriyas, K.S., Swen, R.W., A comparison of the spatiotemporal parameters, kinematics, and 
biomechanics between shod, unshod, and minimally supported running as compared to walking, Phys Ther Sport, 2011, 12, 4, 151-63, https://doi.org/10.1016/j.ptsp.2011.09.004.

24. Farley, C.T., Houdijk, H.H.P., Van Strien, C., Louie, M., Mechanism of leg stiffness adjustment for hopping on surfaces of different stiffnesses, J Appl Physiol, 1998, 85, 3, 1044-55, https://doi.org/10.1152/ jappl.1998.85.3.1044.

25. Bramble, D.M., Lieberman, D.E., Endurance running and the evolution of Homo, Nature, 2004, 432, 7015, 345-52, https://doi. org/10.1038/nature03052.

26. Breine, B., Malcolm, P., Frederick, E.C., De Clercq, D., Relationship between running speed and initial foot contact patterns, Med Sci
Sports Exerc, 2014, 46, 8, 1595-603, https:// doi.org/10.1249/MSS.0000000000000267.

27. Hong, Y., Wang, L., Li, J.X., Zhou, J.H., Comparison of plantar loads during treadmill and overground running, I Sci Med Sport, 2012, 15, 6, 554-60, https://doi. org/10.1016/j. jsams.2012.01.004.

(C) 2020 by the author(s). Published by INCDTPICPI, Bucharest, RO. This is an open access article distributed under the terms and conditions of the Creative Commons Attribution license (http:// creativecommons.org/licenses/by/4.0/). 